\title{
Isolation of a cinnamic acid-metabolizing Clostridium glycolicum strain from oil mill wastewaters and emendation of the species description
}

\author{
1 Laboratoire de \\ Microbiologie IRD, \\ IFR-BAIM, Universités \\ de Provence et de la \\ Méditerranée, ESIL case \\ 925, 163 Avenue de \\ Luminy, 13288 Marseille \\ Cedex 9, France \\ 2 Microbial Research and \\ Discovery Unit, School of \\ Biomolecular and \\ Biomedical Sciences, \\ Faculty of Science, Griffith \\ University, Brisbane, \\ Queensland 4111, \\ Australia
}

\author{
Mohamed Chamkha, ${ }^{1}$ Marc Labat, ${ }^{1}$ Bharat K. C. Patel ${ }^{2}$ \\ and Jean-Louis Garcia ${ }^{1}$
}

Author for correspondence: Jean-Louis Garcia. Tel: +33 49182 8572. Fax: +33491828570. e-mail: garcia@esil.univ-mrs.fr

\begin{abstract}
A strictly anaerobic, Gram-positive, motile, sporulated bacterium, designated strain CIN5, was isolated from olive mill wastewaters after enrichment on cinnamic acid. The rod-shaped cells were slightly curved (0.4-1.1 $\times 2.0-15 \mu \mathrm{m})$ and occurred singly or in pairs. Strain CIN5 utilized a limited number of carbohydrates (glucose, fructose, maltose, sorbitol), grew optimally at $37^{\circ} \mathrm{C}$ and at pH 7.3-7.5 and had a DNA G+C content of 29.1 $\pm 0.3 \mathrm{~mol} \%$. Strain CIN5 was very closely related to Clostridium glycolicum DSM $1288^{\top}$. Both strain CIN5 and the type strain of $C$. glycolicum transformed cinnamic acid to hydrocinnamic acid and a wide range of other cinnamic acid derivatives, including $0-, m$ - and $p$-coumaric, $0-, m$ - and $p$-methoxycinnamic, $p$ methylcinnamic, caffeic, ferulic and isoferulic acids, to their corresponding 3phenylpropionic acids by reducing the double bond of the side chain. Glucose supplementation increased the rate of conversion markedly. The emendation of the description of C. glycolicum is proposed to include these new characteristics.
\end{abstract}

Keywords: Clostridium glycolicum, aromatic compounds, metabolism, emendation, oil mill wastewater

\section{INTRODUCTION}

Olive mill wastewater (OMW) is a major environmental problem in the Mediterranean region, where more than 30 million $\mathrm{m}^{3}$ of this residue are produced annually. The press processing of 1 ton of olives produces $0.5-0.8 \mathrm{~m}^{3}$ of OMW (Boari et al., 1984). The OMW has a dark brown colour, an unpleasant odour and a variable and heterogeneous chemical composition that depends on the olive species, the stage of ripening, the oil-extraction process and the climatic conditions. Chemically, OMW contains sugars, tannins, polyphenols, polyalcohols, pectins, lipids and a wide variety of simple aromatic compounds resulting from olive cell-wall degradation during the oil-extraction process. The main simple phenolic compounds in OMW include tyrosol, hydroxytyrosol and syringic,

Abbreviation: OMW, olive mill wastewater.

The GenBank accession number for the 16S rRNA gene sequence of strain CIN5 is AY007244. $p$-hydroxyphenylacetic, vanillic, veratric, protocatechuic, caffeic, $p$-coumaric and cinnamic acids (Balice \& Cera, 1984; Hamdi, 1993; Labat et al., 2000). The maximum BOD (biological oxygen demand) and COD (chemical oxygen demand) reach 100 and $220 \mathrm{~kg}$ $\mathrm{m}^{-3}$, respectively (Balice et al., 1982). The polyphenols of OMW can inhibit the growth of some bacteria and Hep2 human cells (Capasso et al., 1995).

Catabolism of the main cinnamic compounds derived from the degradation of lignin and other aromatic constituents of plants ( $p$-coumaric, caffeic, ferulic and cinnamic acids) is an important step of the carbon cycle by which natural aromatics and many industrial pollutants are degraded (Andreoni \& Bestetti, 1986). The final fate of these compounds is to reach the soil (Subba Rao et al., 1971). Strains of bacteria, yeast and fungi have been shown to metabolize hydroxycinnamic acids and to be resistant to the inhibitory effects of these compounds (Edlin et al., 1994). Most often, free cinnamic acid derivatives are metabolized by different micro-organisms into 4-vinyl derivatives and then 
reduced into 4-ethyl derivatives; alternatively, these phenolic acids can be reduced first into their substituted phenylpropionic acids and then decarboxyl ated to generate 4-ethyl derivatives. These volatile phenols are potential additives for improving the aroma of wine and other fermented foods and beverages (Cavin et al., 1997). Reduction of the double bound in the side chain of some cinnamic acid derivatives was reported in the rat intestinal microflora (Scheline, 1968), anaerobic microbial consortia (Nali et al., 1985; Angeles de la Torre \& Gomez-Alarcon, 1991), methanogenic consortia (Grbic-Galic \& Young, 1985), Pseudomonas cepacia (Andreoni et al., 1984), Pseudomonas stutzeri and Pseudomonas putida (Andreoni \& Bestetti, 1986), Wolinella succinogenes (Ohmiya et al., 1986) and Corynebacterium glutamicum (Labuda et al., 1993).

We report in this paper the isolation and the characterization of a strain of Clostridium glycolicum from OMW that reduced a wide range of cinnamic acids. We propose to emend the description of the species $C$. glycolicum.

\section{METHODS}

Source of strains. Liquid samples of OMW were collected from the lagoon of an oil olive factory near Marseilles, France, and inoculated anaerobically into basal medium containing $5 \mathrm{mM}$ cinnamic acid as described below. Strain CIN5 was isolated from these enrichment cultures. $C$. glycolicum DSM $1288^{\mathrm{T}}$ was used as a reference culture and was obtained from the DSMZ (Deutsche Sammlung von Mikroorganismen und Zellkulturen, Braunschweig, Germany). The reference culture was routinely grown using glucose-containing basal medium.

Culture media. The anaerobic techniques of Hungate (Hungate, 1969; Macy et al., 1972; Miller \& Wolin, 1974) were used throughout this work. The basal medium contained $\left(1^{-1}\right): 0.4 \mathrm{~g} \mathrm{NH}_{4} \mathrm{Cl}, 0.5 \mathrm{~g} \mathrm{KH}_{2} \mathrm{PO}_{4}, 0.4 \mathrm{~g} \mathrm{NaCl}, 0.33 \mathrm{~g}$ $\mathrm{MgCl}_{2} .6 \mathrm{H}_{2} \mathrm{O}, 0.05 \mathrm{~g} \mathrm{CaCl}_{2} .2 \mathrm{H}_{2} \mathrm{O}, 0.25 \mathrm{~g}$ cysteine $/ \mathrm{HCl}, 2 \mathrm{~g}$ yeast extract (Difco), $1 \mathrm{ml}$ trace element mineral solution (Widdel \& Pfennig, 1981) and $1 \mathrm{mg}$ resazurin. The $\mathrm{pH}$ was adjusted to 7 with $10 \mathrm{M} \mathrm{KOH}$ and the medium was then boiled under a stream of $\mathrm{O}_{2}$-free $\mathrm{N}_{2}$ gas and cooled to room temperature. Five $\mathrm{ml}$ aliquots were dispensed into Hungate tubes, degassed under $\mathrm{N}_{2} / \mathrm{CO}_{2}(80: 20 \%)$ and subsequently sterilized by autoclaving at $110^{\circ} \mathrm{C}$ for $45 \mathrm{~min}$. Prior to inoculation, $0.05 \mathrm{ml} 10 \%$ (w/v) $\mathrm{NaHCO}_{3}$ and $0.05 \mathrm{ml} 5 \%$ (w/v) $\mathrm{Na}_{2} \mathrm{~S} .9 \mathrm{H}_{2} \mathrm{O}$ were injected from sterile stock solutions. Substrates were injected from concentrated anaerobic sterile stock solutions to obtain the desired final concentration.

Enrichment and isolation procedure. Samples $(0.5 \mathrm{ml})$ were inoculated into $5 \mathrm{ml}$ basal medium containing $5 \mathrm{mM}$ cinnamic acid and then incubated at $37^{\circ} \mathrm{C}$. The enrichment was subcultured several times under the same conditions prior to isolation. For isolation, the culture was serially diluted tenfold and single well-isolated colonies that developed in roll tubes (basal medium containing $5 \mathrm{mM}$ cinnamic acid and $1.6 \%$ agar) were picked. This procedure was repeated several times until only one type of colony was observed. Strain CIN5 was maintained in basal medium containing $5 \mathrm{mM}$ cinnamic acid.
Morphology and sporulation test. Light and electron microscopy were performed as described by Fardeau et al. (1997). For testing heat resistance, cells grown in basal medium containing glucose were exposed to temperatures of 80,90 and $100^{\circ} \mathrm{C}$ for $10 \mathrm{~min}$. The cultures were cooled quickly to ambient temperature and inoculated into fresh glucose-containing medium and growth was recorded after $24 \mathrm{~h}$ of incubation at $37^{\circ} \mathrm{C}$. Conditions for sporulation that were tested included growth in the presence of glucose or cinnamic acid or with no added carbon source.

Growth parameters. For all experiments, basal medium containing $0 \cdot 2 \%$ yeast extract and $10 \mathrm{mM}$ glucose was used. The $\mathrm{pH}$ of the pre-reduced anaerobic medium was adjusted with $5 \% \mathrm{NaHCO}_{3}, 5 \% \mathrm{Na}_{2} \mathrm{CO}_{3}$ or $0 \cdot 1 \mathrm{M} \mathrm{HCl}$ to obtain a range of initial $\mathrm{pH}$ values. Different amounts of $\mathrm{NaCl}$ were weighed directly in Hungate tubes prior to dispensing $5 \mathrm{ml}$ medium to obtain the desired $\mathrm{NaCl}$ concentration.

Electron acceptors. Sulfate, thiosulfate, sulfite, nitrate and fumarate $(20 \mathrm{mM})$ and elemental sulfur $(2 \%, \mathrm{w} / \mathrm{v})$ were tested as electron acceptors in basal medium containing $10 \mathrm{mM}$ glucose.

Substrate utilization. Experiments were performed in duplicate with an inoculum subcultured at least once under the same test conditions. The substrates tested for utilization were injected from pre-sterilized and concentrated stock solutions into Hungate tubes that contained $5 \mathrm{ml}$ presterilized basal medium. The following substrates were tested: $20 \mathrm{mM}$ carbohydrates, $20 \mathrm{mM}$ organic acids, $20 \mathrm{mM}$ alcohols, $20 \mathrm{mM}$ betaine, $10 \mathrm{~g}$ peptides $1^{-1}$ and $5 \mathrm{mM}$ aromatic compounds. The concentrated stock solutions were prepared, neutralized if necessary, rendered anaerobic by gassing with $\mathrm{O}_{2}$-free $\mathrm{N}_{2}$ and sterilized by filtration (pore size $0 \cdot 2 \mu \mathrm{m}$; Millipore). Aromatic compounds were tested with or without $5 \mathrm{mM}$ glucose. Autotrophic growth was tested using $\mathrm{H}_{2} / \mathrm{CO}_{2}(20: 80 \%)$ at a final pressure of 2 bar $(200 \mathrm{kPa})$. An increase in $\mathrm{OD}_{580}$ in tubes containing added substrates, compared with control tubes lacking a substrate, was considered to be positive growth.

Analytical techniques. Bacterial growth was monitored by measuring $\mathrm{OD}_{580}$ directly from anaerobic Hungate tubes inserted into the cuvette holder of a spectrophotometer (Shimadzu UV 160A). Aromatic compounds were measured by HPLC by using a chromatograph (Consta Metric 200; LDC-Analytical) equipped with a $\mathrm{C}_{18}$ Symmetry $5 \mu \mathrm{m}$ particle-size column, $250 \mathrm{~mm}$ long, $4.6 \mathrm{~mm}$ i.d. (Waters Chromatography). The column temperature was maintained at $35^{\circ} \mathrm{C}$. An isocratic mobile phase of $30: 69 \cdot 5: 0 \cdot 5$ (by vol) acetonitrile/distilled water/acetic acid was used at a flow rate of $0.6 \mathrm{ml} \mathrm{min}{ }^{-1}$. The volume of the injection loop was $25 \mu \mathrm{l}$. Aromatic compounds were quantified at $240 \mathrm{~nm}$ with a Shimadzu SPD-6A UV detector connected to a CR-6A Shimadzu integrator. Carbohydrates, volatile fatty acids and alcohols were measured by HPLC (Spectra Series 100 model; Thermo Separation Products) equipped with an Aminex HPX-87X 300 mm long, 7.8 mm i.d. column (Bio$\mathrm{Rad}$ ) connected to a differential refractometer (RID-6A, Shimadzu). Analysis was performed using a CR-6A Shimadzu integrator. The mobile phase was $2.5 \mathrm{mM} \mathrm{H}_{2} \mathrm{SO}_{4}$ at a flow rate of $0.5 \mathrm{ml} \mathrm{min} \mathrm{m}^{-1}$ and the column temperature was $35^{\circ} \mathrm{C}$. The volume of the injection loop was $20 \mu \mathrm{l} . \mathrm{H}_{2}$ and $\mathrm{CO}_{2}$ were measured as described by Fardeau et al. (1993).

Determination of the $\mathbf{G}+\mathbf{C}$ content and DNA-DNA hybridization. The $\mathrm{G}+\mathrm{C}$ content of DNA was determined 
by the DSMZ. The DNA was isolated and purified by chromatography on hydroxyapatite (Cashion et al., 1977) and the $\mathrm{G}+\mathrm{C}$ content was determined by using HPLC as described by Mesbah et al. (1989). Non-methylated lambda DNA (Sigma) was used as the standard. DNA-DNA hybridization was performed at the DSMZ as described by De Ley et al. (1970), with the modification described by Escara \& Hutton (1980) and Huß et al. (1983), using a Gilford System model 2600 spectrophotometer equipped with a Gilford model 2527-R thermoprogrammer and plotter. Renaturation rates were computed with the TRANSFER.BAS program of Jahnke \& Bahnweg (1986) and Jahnke (1992).

16S rRNA sequence studies. DNA was extracted as described by Redburn \& Patel (1993) and Andrews \& Patel (1996). The universal primers Fd1 and Rd1 were used to obtain a PCR product of approximately $1.5 \mathrm{~kb}$ corresponding to base positions 8 to 1542 based on Escherichia coli numbering of the 16S rDNA (Winker \& Woese, 1991). The amplification of $16 \mathrm{~S}$ rRNA, sequencing of PCR products and alignment of sequences were performed as described by Baena et al. (1999). Pairwise evolutionary distances based on 1380 unambiguous nucleotides were computed using the programs DNADIST (Jukes \& Cantor, 1969) and NEIGHBOR that form part of the PHYLIP suite of programs (Felsenstein, 1993). TREECON was used extensively for bootstrap analysis (Van de Peer \& De Wachter, 1993).

\section{RESULTS AND DISCUSSION}

\section{Enrichment and isolation}

Growth and acetate production were observed on enrichment cultures in medium containing $5 \mathrm{mM}$ cinnamic acid within 2 weeks of incubation at $37^{\circ} \mathrm{C}$. After several transfers in liquid medium, a stable microbial population developed that degraded cinnamic acid. Several isolates were obtained using the roll-tube method (Hungate, 1969) and one of these cultures, designated strain CIN5, was studied further. Isolation of strain CIN5 from OMW on cinnamic acid is not surprising, as the biotope contains a wide range of aromatic compounds resulting from olive cell-wall degradation during oil extraction (Balice \& Cera, 1984; Hamdi, 1993; Labat et al., 2000). Recently, other strictly anaerobic bacteria were isolated from a methanogenic pilot-scale digester fed with OMW. Two of these, Eubacterium aggregans (Mechichi et al., 1998) and Clostridium methoxybenzovorans (Mechichi et al., 1999a), demethylate some methoxylated aromatic compounds without ring cleavage. Another anaerobe found in this digester, Sporobacterium olearium, utilizes a range of aromatic compounds, methanol and crotonate as carbon and energy sources. Demethoxylation is the initial key reaction for the subsequent degradation of methoxylated compounds (Mechichi et al., 1999b).

\section{Morphology and physiology}

Cells of strain CIN5 were Gram-positive, straight to slightly curved rods, $0 \cdot 4-1 \cdot 1 \times 2 \cdot 0-15 \mu \mathrm{m}$ and motile and occurred singly or in pairs. Sporulated cells were not abundant in late exponential growth phase. However, sporulation occurred readily after incubation of culture for $10 \mathrm{~min}$ at $80^{\circ} \mathrm{C}$. Spores were oval, usually subterminal and non-swelling. Positive growth was obtained in fresh medium after inoculation of cultures that had been incubated for $10 \mathrm{~min}$ at $80^{\circ} \mathrm{C}$, but not at $90{ }^{\circ} \mathrm{C}$ or $100{ }^{\circ} \mathrm{C}$, indicating resistance to heat.

Strain CIN5 is a mesophilic and strictly anaerobic bacterium. The temperature range for growth was $20-42{ }^{\circ} \mathrm{C}$, with optimal growth occurring at $37^{\circ} \mathrm{C}$. No growth occurred at 10 or $45^{\circ} \mathrm{C}$. The initial $\mathrm{pH}$ range for growth was $\mathrm{pH} 6 \cdot 0-9 \cdot 4$ with an optimum at $\mathrm{pH}$ $7 \cdot 3-7 \cdot 5$. The $\mathrm{NaCl}$ concentration range for growth was $0-50 \mathrm{~g} \mathrm{l}^{-1}$. Growth was inhibited markedly above $40 \mathrm{~g}$ $\mathrm{NaCl}^{-1}$. Yeast extract was required for growth and could be used as the sole carbon and energy source. Strain CIN5 fermented ethylene glycol, propylene glycol and glycerol, a limited number of carbohydrates including glucose, fructose, maltose and sorbitol, the organic acid succinate and peptides including yeast extract, Casamino acids, Biotrypcase and peptone. Isolate CIN5 did not utilize arabitol, cellobiose, galactose, lactose, mannitol, mannose, melibiose, myoinositol, raffinose, ribose, sorbose, trehalose, acetate, adipate, butyrate, crotonate, formate, isobutyrate, lactate, malate, propionate, valerate, ethanol, 2-propanol, methanol, propanol, betaine, gelatin or $\mathrm{H}_{2} / \mathrm{CO}_{2}$. Ethylene glycol was fermented into acetate and ethanol, propylene glycol was fermented into propionate, propanol and small amounts of acetate and ethanol, glycerol was fermented into ethanol, acetate, $\mathrm{CO}_{2}$ and $\mathrm{H}_{2}$, glucose was fermented into ethanol, formate, acetate, $\mathrm{CO}_{2}$ and $\mathrm{H}_{2}$ and succinate was fermented into propionate and $\mathrm{CO}_{2}$. Acetate, isovalerate, ethanol, $\mathrm{H}_{2}$ and $\mathrm{CO}_{2}$ were produced from the utilization of yeast extract, Casamino acids and Biotrypcase. Acetate, isovalerate and $\mathrm{CO}_{2}$ were produced from peptone utilization. Sulfate, thiosulfate, sulfite, elemental sulfur, nitrate and fumarate could not be used as electron acceptors.

\section{G + C content, 16S rRNA sequence analysis and DNA-DNA relatedness}

The DNA G + C content of strain CIN 5 was $29 \cdot 1 \pm 0 \cdot 3$ $\mathrm{mol} \%$. Using twelve primers, we determined an almost complete sequence consisting of 1493 bases of the $16 \mathrm{~S}$ rRNA gene of strain CIN5 (corresponding to E. coli positions 15-1539; Winker \& Woese, 1991). Phylogenetic analysis revealed that strain CIN5 was a member of the low-G+C-content Gram-positive branch and grouped with members of cluster XI (Collins et al., 1994). Strain CIN5 was found to be closely related to C. glycolicum (Gaston \& Stadtman, 1963), with only four nucleotide differences between the two 16S rRNA sequences. The level of DNA-DNA relatedness between strain CIN5 and C. glycolicum DSM $1288^{\mathrm{T}}$ was $79 \%$. The DNA G $+\mathrm{C}$ content of strain CIN5 is the same that of C. glycolicum (Johnson \& Francis, 1975). Phenotypically, both strains are 
straight to slightly curved rods, occurring singly or in pairs, motile and spore-formers. They grow at mesophilic temperatures, ferment ethylene glycol, propylene glycol, a limited number of carbohydrates and some peptides and are unable to hydrolyse gelatin (Cato et al., 1986). The phylogenetic, genotypic and phenotypic characteristics of isolate CIN5 indicate that it is a member of the genus Clostridium and a strain of $C$. glycolicum.

C. glycolicum has been isolated from soil, mud, snake venom, bovine intestine, human faeces and clinical specimens including wounds, abscesses and peritoneal fluid (Drasar et al., 1976; Finegold et al., 1983). The isolation of strain CIN5 from OMW extends the known habitat for C. glycolicum.

\section{Metabolism of aromatic compounds}

Strain CIN5 metabolized various cinnamic acids to their corresponding 3-phenylpropionic (hydrocinnamic) acid derivatives. After $2 \mathrm{~d}$ of anaerobic incubation at $37^{\circ} \mathrm{C}$, isolate CIN5 converted cinnamic acid to 3-phenylpropionic acid, $o$-coumaric acid to 3(2-hydroxyphenyl) propionic acid, $m$-coumaric acid to 3-(3-hydroxyphenyl) propionic acid, $p$-coumaric acid to 3-(4-hydroxyphenyl) propionic acid, $o$ methoxycinnamic acid to 3-(2-methoxyphenyl) propionic acid, $m$-methoxycinnamic acid to 3-(3-methoxyphenyl) propionic acid, $p$-methoxycinnamic acid to 3(4-methoxyphenyl) propionic acid, $p$-methylcinnamic acid to 3-(4-methylphenyl) propionic acid and isoferulic acid to 3-(3-hydroxy-4-methoxyphenyl) propionic acid, with or without $5 \mathrm{mM}$ glucose. Caffeic acid and ferulic acid were metabolized by strain CIN5 to 3-(3,4-dihydroxyphenyl) propionic acid at $52 \%$ and 3-(4-hydroxy-3-methoxyphenyl) propionic acid at $57 \%$, respectively, after $2 \mathrm{~d}$ of incubation. However, with glucose supplementation, the conversion of caffeic and ferulic acids was complete after $2 \mathrm{~d}$. Transformation was complete, regardless of the presence of glucose in the medium, after $4 \mathrm{~d}$ of incubation.

The amount of phenylpropionic acid derivatives produced by strain CIN5 equalled that of cinnamic acids consumed. The ratio of phenylpropionic acids to their corresponding cinnamic acids in the medium increased during the course of the experiment until substrate utilization was complete. By contrast, strain CIN5 did not reduce 3,4,5-trimethoxycinnamic acid; substitution of both of the meta positions and the para position $(3,4,5)$ with methoxyl groups on the aromatic ring inhibited the biotransformation. Cinnamyl alcohol, cinnamaldehyde, styrene, oestragole (4-allylanisole), eugenol(4-allyl-2-methoxyphenol)and phenylpropionic acids [3-phenylpropionic acid (hydrocinnamic acid) and 3,4-dihydroxyphenylpropionic acid (hydrocaffeic acid)] were not metabolized by strain CIN5, indicating that the composition of the side chain determined the substrate specificity; an acrylic acid side chain was required by $C$. glycolicum for the biotransformation of aromatic compounds.
Other aromatic compounds tested at $5 \mathrm{mM}$ in basal medium, with or without $5 \mathrm{mM}$ glucose, were not used by strain CIN5. They included benzoate, hydroxylated benzoic acids [4-hydroxybenzoate, 2,4-, 2,6-, 3,4- and 3,5-dihydroxybenzoates, 2,4,6-trihydroxybenzoate and 3,4,5-trihydroxybenzoate (gallate)], methoxylated benzoic acids (2,4-, 2,6-, 3,4- and 3,5-dimethoxybenzoates and 3,4,5-trimethoxybenzoate), mixed hydroxylated/methoxylated benzoic acids [4-hydroxy-3-methoxybenzoate (vanillate) and 3-hydroxy-4-methoxybenzoate (isovanillate)], 3,4-dimethylbenzoic acid, gallic acid methyl ester, p-hydroxyphenylethanol (1,4-tyrosol) and 3,4,5-trihydroxybenzene (pyrogallol). No ring cleavage was observed with any of the aromatic compounds tested, even after 2 weeks of incubation.

The metabolism of cinnamic compounds by the type strain of C. glycolicum was similar to that observed with strain CIN5. The metabolism of various cinnamic acids by isolate CIN5 and the type strain of $C$. glycolicum involved the reduction of the double bound in the side chain. Corresponding phenylpropionic acids were always the end-products, without further degradation. With all aromatic substrates used by both strains, adding glucose enhanced growth and accelerated this conversion markedly. The presence of cinnamic acids did not result in higher growth yields, so cinnamic acids cannot be used as the carbon and energy source. Cinnamic acids function in both of these strains as terminal electron acceptors in the oxidation of $\mathrm{H}_{2}$. Hydrogen produced from yeast extract or glucose utilization can be used by strain CIN5 or the type strain of C. glycolicum to reduce the double bond in the side chain. Many micro-organisms cannot degrade aromatic compounds completely, but catalyse oxygen-independent biotransformations without ring cleavage. The effect of reductive anaerobic biotransformations of aromatic substrates is to dispose of redox equivalents generated in oxidative reactions. The known reductive biotransformation reactions are either involved in anaerobic respiratory chains or are part of fermentative pathways (Heider \& Fuchs, 1997). The processes are exergonic and in some cases are even associated with energy conservation.

Our results indicate that both the type strain of $C$. glycolicum and strain CIN5 transform 11 cinnamic acids and, hence, we propose to emend the description of $C$. glycolicum to include these new traits.

\section{Emended description of Clostridium glycolicum (Gaston and Stadtman 1963)}

Clostridium glycolicum (gly.co'li.cum. L. adj. suff. -icus related to, belonging to; N.L. neut. adj. glycolicum referring to the ability to ferment ethylene glycol).

Cells are strictly anaerobic, Gram-positive, straight to slightly curved rods, motile and peritrichous, $0 \cdot 3-$ $1.3 \times 1 \cdot 8-15.4 \mu \mathrm{m}$, occurring singly or in pairs. Spores are oval and usually subterminal, occasionally terminal, often occurring as free spores and not swelling. 
Surface colonies are 1-4 mm, circular to irregular, raised to convex, translucent to semi-opaque, greyish white, shiny and smooth with a granular, mottled or mosaic internal structure and entire, scalloped or erose margins. The optimum temperature for growth is $30-37^{\circ} \mathrm{C}$ at $\mathrm{pH} 7 \cdot 3-7 \cdot 6$. Most strains grow moderately well at $20{ }^{\circ} \mathrm{C}$, poorly if at all at $45^{\circ} \mathrm{C}$. Growth is inhibited by $6.5 \% \mathrm{NaCl}, 20 \%$ bile and $\mathrm{pH} 9.5$. Yeast extract is required for growth and can be used as the sole carbon and energy source. Ferments ethylene glycol to acetate and ethanol and propylene glycol to propionate, propanol and small amounts of acetate and ethanol. Sugars fermented are glucose, fructose, sorbitol, xylose, maltose and dulcitol, with acid and gas formation. Succinate is fermented into propionate and $\mathrm{CO}_{2}$, glycerol is fermented into acetate, ethanol, $\mathrm{H}_{2}$ and $\mathrm{CO}_{2}$, yeast extract, Casamino acids and Biotrypcase are fermented into acetate, isovalerate, ethanol, $\mathrm{H}_{2}$ and $\mathrm{CO}_{2}$ and peptone is fermented into acetate, isovalerate and $\mathrm{CO}_{2}$. Substrates not fermented include amygdalin, arabinose, cellobiose, galactose, glycogen, inulin, lactose, mannitol, mannose, melezitose, melibiose, raffinose, rhamnose, ribose, salicin, sucrose and trehalose. Degrades uracil to $\beta$-alanine, ammonia and $\mathrm{CO}_{2}$. Threonine is converted to propionate. Products in PYG broth are acetic, isovaleric and isobutyric acids and ethyl, propyl, isobutyl and isoamyl alcohols; propionic, formic, lactic and succinic acids may also be detected. Abundant $\mathrm{H}_{2}$ is produced. Lecithinase, lipase, indole and caproic and butyric acids are not produced. Starch and gelatin are not hydrolysed. Sulfate, thiosulfate, sulfite, elemental sulfur, nitrate and fumarate are not reduced and lactate is not utilized. Reduces the double bond of the side chain of a wide range of cinnamic acids: cinnamic, $o-, m$ - and $p$-coumaric, $o$-, $m$ - and $p$-methoxycinnamic, $p$-methylcinnamic, caffeic, ferulic and isoferulic acids. The end-products of metabolism of cinnamic acids are the corresponding phenylpropionic acids: 3-phenyl, 3-(2-hydroxyphenyl), 3-(3-hydroxyphenyl), 3-(4-hydroxyphenyl), 3-(2-methoxyphenyl), 3-(3methoxyphenyl), 3-(4-methoxyphenyl), 3-(4-methylphenyl), 3-(3,4-dihydroxyphenyl), 3-(4-hydroxy-3methoxyphenyl) and 3-(3-hydroxy-4-methoxyphenyl) propionic acids. Glucose supplementation increases the rate of conversion markedly. The genomic DNA $\mathrm{G}+\mathrm{C}$ content is $29 \mathrm{~mol} \%$. Member of cluster XI of the low-G+C-content Gram-positive branch. The habitat includes soil, mud, oil mill wastewater, snake venom, bovine intestine, human faeces and clinical specimens including wounds, abscesses and peritoneal fluid.

The type strain is ATCC $14880^{\mathrm{T}}\left(=\mathrm{NCIB} 10632^{\mathrm{T}}=\right.$ DSM 1288 ${ }^{\mathrm{T}}$ ). Strain CIN5 (= DSM $13561=$ CIP 106672) is a reference strain.

\section{ACKNOWLEDGEMENTS}

Financial assistance to M.C. from the Tunisian Minister for Superior Teaching and the French Research Institute for Development and to B.K.C.P. from the Australian Re- search Council is gratefully acknowledged. We are indebted to P. A. Roger for improving the manuscript.

\section{REFERENCES}

Andreoni, V. \& Bestetti, G. (1986). Comparative analysis of different Pseudomonas strains that degrade cinnamic acid. Appl Environ Microbiol 52, 930-934.

Andreoni, V., Galli, E. \& Galliani, G. (1984). Metabolism of ferulic acid by a facultatively anaerobic strain of Pseudomonas cepacia. Syst Appl Microbiol 5, 299-304.

Andrews, K. T. \& Patel, B. K. C. (1996). Fervidobacterium gondwanense sp. nov., a new thermophilic anaerobic bacterium isolated from nonvolcanically heated geothermal waters of the Great Artesian Basin of Australia. Int J Syst Bacteriol 46, 265-269.

Angeles de la Torre, M. \& Gomez-Alarcon, G. (1991). Ferulic acid anaerobic degradation by marsh sediment microorganisms. Microbios 68, 119-127.

Baena, S., Fardeau, M.-L., Ollivier, B., Labat, M., Thomas, P., Garcia, J.-L. \& Patel, B. K. C. (1999). Aminomonas paucivorans gen. nov., sp. nov., a mesophilic, anaerobic, amino-acidutilizing bacterium. Int J Syst Bacteriol 49, 975-982.

Balice, V. \& Cera, O. (1984). Acidic phenolic fraction of the juice of olives determined by gas chromatographic method. Grasas Aceites 25, 178-180.

Balice, V., Boari, G., Cera, O. \& Abbaticchio, P. (1982). Indagine analitica sulle acque di vegetazione. Nota 1. Inquinamento 7 , 49-53.

Boari, G., Brunetti, A., Passino, R. \& Rozzi, A. (1984). Anaerobic digestion of olive oil mill wastewaters. Agric Wastes 10, 161-175.

Capasso, R., Evidente, A., Schivo, L., Orru, G., Marcialis, M. A. \& Cristinzio, G. (1995). Antibacterial polyphenols from olive oil mill waste waters. J Appl Bacteriol 79, 393-398.

Cashion, P., Holder-Franklin, M. A., McCully, J. \& Franklin, M. (1977). A rapid method for the base ratio determination of bacterial DNA. Anal Biochem 81, 461-466.

Cato, E. P., George, W. L. \& Finegold, S. M. (1986). Genus Clostridium Prazmowski 1880. In Bergey's Manual of Systematic Bacteriology, vol. 2, pp. 1141-1200. Edited by P. H. A. Sneath, N. S. Mair, M. E. Sharpe \& J. G. Holt. Baltimore: Williams \& Wilkins.

Cavin, J.-F., Barthelmebs, L. \& Diviès, C. (1997). Molecular characterization of an inducible $p$-coumaric acid decarboxylase from Lactobacillus plantarum: gene cloning, transcriptional analysis, overexpression in Escherichia coli, purification, and characterization. Appl Environ Microbiol 63, 1939-1944.

Collins, M. D., Lawson, P. A., Willems, A., Cordoba, J. J., Fernandez-Garayzabal, J., Garcia, P., Cai, J., Hippe, H. \& Farrow, J. A. E. (1994). The phylogeny of the genus Clostridium: proposal of five new genera and eleven new species combinations. Int $J$ Syst Bacteriol 44, 812-826.

De Ley, J., Cattoir, H. \& Reynaerts, A. (1970). The quantitative measurement of DNA hybridization from renaturation rates. Eur J Biochem 12, 133-142.

Drasar, B. S, Goddard, P., Heaton, S., Peach, S. \& West, B. (1976). Clostridia isolated from faeces. J Med Microbiol 9, 63-71.

Edlin, D. A. N., Narbad, A., Dickinson, J. R. \& Lloyd, D. (1994). The biotransformation of simple phenolic compounds by Brettanomyces anomalus. FEMS Microbiol Lett 125, 311-316.

Escara, J. F. \& Hutton, J. R. (1980). Thermal stability and 
renaturation of DNA in dimethyl sulfoxide solutions: acceleration of the renaturation rate. Biopolymers 19, 1315-1327.

Fardeau, M.-L., Cayol, J.-L., Magot, M. \& Ollivier, B. (1993). $\mathrm{H}_{2}$ oxidation in the presence of thiosulfate, by a Thermoanaerobacter strain isolated from an oil-producing well. FEMS Microbiol Lett 113, 327-332.

Fardeau, M.-L., Ollivier, B., Patel, B. K. C., Magot, M., Thomas, P., Rimbault, A., Rocchiccioli, F. \& Garcia, J.-L. (1997). Thermotoga hypogea sp. nov., a xylanolytic, thermophilic bacterium from an oil-producing well. Int J Syst Bacteriol 47, 1013-1019.

Felsenstein, J. (1993) PHYLIP (Phylogenetic Inference Package) version 3.51c. Distributed by the author, Department of Genetics, University of Washington, Seattle, WA, USA.

Finegold, S. M., Sutter, V. L. \& Mathisen, G. E. (1983). Normal indigenous intestinal flora. In Human Intestinal Microflora in Health and Disease, pp. 3-31. Edited by D. J Hentges. New York: Academic Press.

Gaston, L. W. \& Stadtman, E. R. (1963). Fermentation of ethylene glycol by Clostridium glycolicum, sp. n. J Bacteriol 85, 356-362.

Grbic-Galic, D. \& Young, L. Y. (1985). Methane fermentation of ferulate and benzoate: anaerobic degradation pathways. Appl Environ Microbiol 50, 292-297.

Hamdi, H. (1993). Future prospects and constraints of olive mill wastewaters use and treatment: a review. Bioprocess Eng 8, 209-214.

Heider, J. \& Fuchs, G. (1997). Microbial anaerobic aromatic metabolism. Anaerobe 3, 1-22.

Hungate, R. E. (1969). A roll-tube method for the cultivation of strict anaerobes. Methods Microbiol 136, 194-198.

Huß, V. A. R., Festel, H. \& Schleifer, K. H. (1983). Studies on the spectrometric determination of DNA hybridization from renaturation rates. Syst Appl Microbiol 4, 184-192.

Jahnke, K.-D. (1992). Basic computer program for evaluation of spectroscopic DNA renaturation data from GILFORD System 2600 spectrometer on a PC/ XT/AT type personal computer. $J$ Microbiol Methods 15, 61-73.

Jahnke, K.-D. \& Bahnweg, G. (1986). Assessing natural relationships in the basidiomycetes by DNA analysis. Trans $\mathrm{Br}$ Mycol Soc 87, 175-191.

Johnson, J. L. \& Francis, B. S. (1975). Taxonomy of the clostridia: ribosomal ribonucleic acid homologies among the species. $J$ Gen Microbiol 88, 229-244.

Jukes, T. H. \& Cantor, C. R. (1969). Evolution of protein molecules. In Mammalian Protein Metabolism, vol. 3, pp. 21-132. Edited by H. N. Munro. New York: Academic Press.

Labat, M., Augur, C., Perraud-Gaime, I., Roussos, S. \& Sayadi, S. (2000). Biotechnological potentialities of polyphenolic compounds of coffee and comparison with olive, In Coffee Biotechnology and Quality, pp. 517-531. Edited by T. Sera, C. R. Soccol, A. Pandey \& S. Roussos. Dordrecht: Kluwer.

Labuda, I. M., Keon, K. A. \& Goers, S. K. (1993). Microbial bioconversion process for the production of vanillin. In
Progress in Flavor Precursor Studies. Analysis-GenerationBiotechnology, pp. 477-482. Edited by P. Schreier \& P. Winterhalter. Carol Stream, IL: Allured.

Macy, J. M., Snellen, J. E. \& Hungate, R. E. (1972). Use of syringe methods for anaerobiosis. Am J Clin Nutr 25, 1318-1323.

Mechichi, T., Labat, M., Woo, T. H. S., Thomas, P., Garcia, J.-L. \& Patel, B. K. C. (1998). Eubacterium aggregans sp. nov., a new homoacetogenic bacterium from olive mill wastewater treatment digestor. Anaerobe 4, 283-291.

Mechichi, T., Labat, M., Patel, B. K. C., Woo, T. H. S., Thomas, P. \& Garcia, J.-L. (1999a). Clostridium methoxybenzovorans sp. nov., a new aromatic $o$-demethylating homoacetogen from an olive mill wastewater treatment digester. Int J Syst Bacteriol 49, 1201-1209.

Mechichi, T., Labat, M., Garcia, J.-L., Thomas, P. \& Patel, B. K. C. (1999b). Sporobacterium olearium gen. nov., sp. nov., a new methanethiol-producing bacterium that degrades aromatic compounds, isolated from an olive mill wastewater treatment digester. Int J Syst Bacteriol 49, 1741-1748.

Mesbah, M., Premachandran, U. \& Whitman, W. B. (1989). Precise measurement of the $\mathrm{G}+\mathrm{C}$ content of deoxyribonucleic acid by high-performance liquid chromatography. Int J Syst Bacteriol 39, 159-167.

Miller, T. L. \& Wolin, M. J. (1974). A serum bottle modification of the Hungate technique for cultivating obligate anaerobes. Appl Microbiol 27, 985-987.

Nali, M., Rindone, B., Tollari, S., Andreoni, V. \& Treccani, V. (1985). Anaerobic microbial conversion of three hydroxycinnamic acids. Experientia 41, 1351-1353.

Ohmiya, K., Takeuchi, M., Chen, W., Shimizu, S. \& Kawakami, H. (1986). Anaerobic reduction of ferulic acid to dihydroferulic acid by Wolinella succinogenes from cow rumen. Appl Microbiol Biotechnol 23, 274-279.

Redburn, A. C. \& Patel, B. K. C. (1993). Phylogenetic analysis of Desulfotomaculum thermobenzoicum using polymerase chain reaction-amplified 16S rRNA-specific DNA. FEMS Microbiol Lett 113, 81-86.

Scheline, R. R. (1968). Metabolism of phenolic acids by the rat intestinal microflora. Acta Pharmacol Toxicol 26, 189-205.

Subba Rao, P. V., Nambudiri, A. M. D. \& Bhat, J. V. (1971). Microbial degradation of phenylpropanoid compounds. $J$ Sci Ind Res 30, 663-679.

Van de Peer, Y. \& De Wachter, R. (1993). TREECON: a software package for the construction and drawing of evolutionary trees. Comput Appl Biosci 9, 177-182.

Widdel, F. \& Pfennig, N. (1981). Studies on dissimilatory sulfatereducing bacteria that decompose fatty acids. I. Isolation of new sulfate-reducing bacteria enriched with acetate from saline environments. Description of Desulfobacter postgatei gen. nov., sp. nov. Arch Microbiol 129, 395-400.

Winker, S. \& Woese, C. R. (1991). A definition of the domains Archaea, Bacteria and Eucarya in terms of small subunit ribosomal RNA characteristics. Syst Appl Microbiol 13, 161-165. 